\title{
Formulation and Stability Testing of Griseovulfin Microemulsion
}

\author{
Iyan Sopyan $^{1,2}$, Dolih Gozali ${ }^{1}$, Eka Paramudya $^{1}$ \\ ${ }^{1}$ Departement of Pharmacutics and Technology of Pharmacy, Faculty of Pharmacy, Universitas Padjadjaran. \\ Sumedang, Indonesia \\ ${ }^{2}$ Research Center of Drugs discovery and Drugs Development Faculty of Pharmacy, Universitas \\ Padjadjaran, Bandung, Indonesia.
}

Received : 10 Dec 2018/Revised : 30 Dec 2018/Accepted : 2 Jan 2019/ Published : 23 Jun 2020

\begin{abstract}
The use of drugs that are less soluble in water will become clinically less efficient, this is caused by the low penetration of the drug into the body. A microemulsion is a dispersion system such as an emulsion that can increase the solubility of drugs that are sometimes difficult to dissolve in water. Microemulsions have long-term stability, clear, transparent, and good penetration capabilities. In this study, a microemulsion formulation with active ingredients griseofulvin and virgin coconut oil was conducted as an oil phase. The resulting microemulsion evaluates physical stability during 35 storage days. The results showed that the microemulsion preparation remained stable during storage time without changes in color, odor, and consistency, while the $\mathrm{pH}$ and dosage viscosity experienced less significant changes. The consequences of the centrifugation test at $3700 \mathrm{rpm}$ for 5 hours and freezing tests for 24 days showed stable preparation and cannot be separated. The diffusion test results obtained by FG2 had the largest permeation percentages of 3.6136\%, FG3 2.8724\%, and the smallest FG1 $2.0477 \%$.
\end{abstract}

Keywords: microemulsion, griseofulvin, stability, diffusion test

\section{Introduction}

The solubility of a nutritious substance plays an important role in the formulation of a pharmaceutical preparation [1]. More than $50 \%$ of new chemical compounds found today are hydrophobic. The clinical use of hydrophobic drugs becomes inefficient with low solubility, resulting in a small penetration of the drug in the body[2]. Griseofulvin is a substance that is very difficult to dissolve in water and ethanol (95\%), but easily dissolved in tetrachloroethane [3]. Griseofulvin is produced by Penicillium griseofulvin and it was uesd for oral route as fungistatic against many dermatophytes [4,5] The dosage forms that are widely used for griseofulvin are tablets, oral suspensions, capsules, and ultramicrosize tablets with this approach the absorption is very limited so efforts are needed to increase the dissolution, especially in local route administration. The effort that can be done is to use enhancers and reduce particles such as microemulsions.. One way to increase the solubility of a drug that is lipophilic or hydrophobic is to make an emulsion preparation. Emulsion is a preparation containing liquid drug ingredients or drug solutions, dispersed in a carrier liquid, stabilized with an emulsifying agent or a suitable surfactant [3]. The purpose of emulsion formation is that the medicinal material has an unpleasant taste and composition which can be made more comfortable in oral administration if it is 
formulated in the form of an emulsion, and is easily absorbed [6]. Emulsions are thermodynamically unstable systems that consist of at least two liquid phases which are not mixed, one of which is dispersed in the form of drops (dispersed phase) in the other liquid phase (continuous phase), stabilized by an emulsifying agent. This dispersion is unstable, these grains combine to form two separate layers of water and oil [7].

A dispersion system developed from an emulsion preparation. When compared to emulsions, there are many characteristics of microemulsions that make these preparations attractive for use as a drug delivery system. Among others, it has a long-term stability, clear and transparent, can be sterilized by filtration, low manufacturing costs, has a high solubility and has good penetrating ability. These characteristics make microemulsion have an important role as an alternative in formulas for active substances that are not soluble [8].

Microemulsions have great solubility in both water and oil and microemulsions can be formed for sustained release preparations. It is known that microemulsions are used to improve bioavailability in drug administration, for example in topical and oral administration. Microemulsions are commonly used for topical preparations where there is an increase in drug absorption [9].

In this research we use VCO in formulation as enhancer and propylene glycol as cosolvent to form emulsion to be microemulsion, so microemulsion will be performed an enhancing of griseofulvin.Absorption especially in topical administration.

\section{Materials and Methods}

\subsection{Materials}

The materials used in the study were Aquadestilata, Aquabidestilata, Griseofulvin was purchased from PT Kimia Farma, potassium dihydrogen phosphate (Quadrant), sodium hydroxide (Quadrant), propilenglikol (Bratachem), span 80 (Quadrant),t 80 (Bratachem), and virgin coconut oil (PT Wuwung Prada Pratama Yogyakarta).

\subsection{Equipments}

The equipment used in this study was the Stirrer motor RZR 2021 (Heidolph), the UV spectrophotometer (Specoord. The Jena analytic), the $\mathrm{pH}$ meter ( $\mathrm{pH}$ meter 744 Methrom), centrifugation (Hettich Zentrifugen)

\subsection{Methods}

The stages in the research method used are the collection of ingredients, Griseofulvin microemulsion preparations, evaluation of dosage, permeation test, analysis, and data processing.

\subsubsection{Microemultion Formulation}

The preparation of the microemulsion is to dissolve the Tween 80 in the water and the constantly stirred using an ultraturax stirrer motor at a temperature of $50^{\circ} \mathrm{C}$ at $1200 \mathrm{rpm}$ so that a clear solution is obtained. Griseofulvin dissolved in Propilenglikol then inserted into the dispersion span in the VCO that serves as the oil phase. This dispersion is inserted into the water phase, stirring with an ultrathurax mixer for 30 minutes at a speed of $2200 \mathrm{rpm}$ to a clear and transparent microemulsion.

\subsubsection{Dosage evaluation}

Some tests were conducted to determine the stability of microemulsion preparations and Griseofulvin emulsions, among others.

\section{Organoleptic Observation}

Organoleptic observations of microemulsions and griseofulvin emulsions were examined by observing changes in consistency, color, odor, and homogeneity during storage.

\section{2. $\mathrm{pH}$ observation}

$\mathrm{PH}$ measurement using a $\mathrm{pH}$ indicator. Measurements were taken at room temperature on days $1,3,5,7,14,21,28$, and 35 days.

\section{Determintion of viscosity}

Viscosity measurements were carried out using a Brookfield Viscometer. The trick is that the spindle is mounted in place and arranged so that the spindle boundary is immersed into the preparation that has 
been placed on the beaker. The tool is turned on and the spindle is left to rotate until the needle shows a constant number [10].

\section{Centrifugation test}

Griseofulvin microemulsion preparations of approximately $10 \mathrm{ml}$ were put into centrifugation tubes then centrifuged for 5 hours at $3700 \mathrm{rpm}$.

\section{Freeze-thaw studies}

Evaluation of physical preparations using the freeze-thaw method was carried out at low temperature $\left(4^{0} \mathrm{C}\right)$ and high temperature $\left(40^{\circ} \mathrm{C}\right)$ for 6 cycles. One cycle consists of 48 hours at low temperatures and 48 hours at high temperatures.

6. In vitro permeation testing of microemulsion preparations using cellulose membranes. The stages of testing are as follows:

\subsubsection{Material Preparation}

a. Preparation of receptor fluids (phosphate buffer pH 7.4).

Making phosphate buffer $\mathrm{pH} 7.4$ according to Pharmacopoeia Indonesia edition III by mixing 50 $\mathrm{ml}$ of potassium dihydrogen phosphate (KH2PO4) $0.2 \mathrm{M}$ and then adding $39.1 \mathrm{ml}$ of sodium hydroxide $(\mathrm{NaOH}) \quad 0.2 \mathrm{~N}$ and diluted with enough carbon dioxide water to $200 \mathrm{~mL}[3]$

\section{b. Spangler Fluid Preparation}

All ingredients such as cholesterol, stearic acid, palmitic acid, oleic acid, vaseline albumin, paraffin liquid, and squalene stir homogeneously and are melted in a water bath. After everything is mixed, Whatman paper number 1 is put into the liquid then impregnated for 15 minutes. Dry by placing Whatman paper on filter paper [11].

\subsubsection{Determination of analysis method of} griseofulvin microemulsion permeation study

a. Making griseofulvin raw solution

The standard solution is made at a concentration of $800 \mathrm{ppm}$ by weighing $80 \mathrm{mg}$ of griseofulvin dissolved in $100 \mathrm{ml}$ phosphate buffer. b. Determination of griseofulvin maximum absorption wavelength

From the standard solution of griseofulvin, dilution of $2 \mathrm{ppm}$ is made and themaximumwavelength is sought.

c. Making the griseofulvin raw curve

Making the griseofulvin standard curve by using dilutions of various concentrations from $0.5 \mathrm{ppm}, 1$ ppm, $1.5 \mathrm{ppm}, 2 \mathrm{ppm}$, and $2.5 \mathrm{ppm}$.

\subsubsection{Permeation study of griseofulvin microemultion}

Permeation tests were carried out using a Franz diffusion cell device consisting of cellulose membrane permeation cells, peristaltic pumps, magnetic stirrers, beaker glass, hot plates, receptor receptors, thermometers, and silicone hoses. The test preparation was weighed 1 gram and then leveled over the membrane. The temperature of the media is $370 \mathrm{C}$ with a total volume of $100 \mathrm{ml}$ of receptor fluid. The peristaltic pump sucks the receptor fluid from the beaker and is then pumped to the cell so that a hydrodynamic flow takes place. Samples were taken from the permeation media at 30, 60, 90, and 120 minutes [12].

\section{Results and Disscusion}

\subsection{Results of griseofulvin microemulsion formulation}

In the microemulsion formulation process, a preliminary experiment involves determining the conditions of the experiment and determining the composition of the appropriate material to produce clear microemulsion preparations. Based on these preliminary experiments, the results of griseofulvin microemulsion formulations resulted in clear and stable preparations as listed in the following Table 1.

The active substance which is used as a model for making microemulsion preparations is griseofulvin. Microemulsion preparation uses virgin coconut oil which is pure coconut oil derived from fresh coconut meat as the oil phase. The surfactants used are Tween 80 and Span 80 [13]. Propylene glycol used in this formula functions as a cosolvent. 
Table 1: The results of griseofulvin microemulsion with variations in surfactant concentrations

Notice:

\begin{tabular}{lcccc}
\multicolumn{1}{c}{ Materials } & FG0 & FG1 & FG2 & FG3 \\
\hline Griseofulvin & - & $0.5 \%$ & $0.5 \%$ & $0.5 \%$ \\
Tween 80 & $30 \%$ & $30 \%$ & $35 \%$ & $40 \%$ \\
Span 80 & $20 \%$ & $20 \%$ & $15 \%$ & $10 \%$ \\
Propilenglikol & $25 \%$ & $25 \%$ & $25 \%$ & $25 \%$ \\
VCO & $5 \%$ & $5 \%$ & $5 \%$ & $5 \%$ \\
Aquadest & $20 \%$ & $20 \%$ & $20 \%$ & $20 \%$ \\
& Clear yellow & Clear yellow & Clear yellow & Clear yellow \\
\hline
\end{tabular}

FG0: Microemulsion formula with Tween 80 as much as $30 \%$, Span 80 as much as $20 \%$ without the addition of Griseofulvin.

FG1: Microemulsion formula with Tween 80 as much as $30 \%$, Span 80 as much as $20 \%$, and Griseofulvin $0.5 \%$. FG2: Microemulsion formula with Tween 80 as much as $35 \%$, Span 80 as much as $15 \%$, and Griseofulvin $0.5 \%$. FG3: Microemulsion formula with Tween 80 as much as $40 \%$, Span 80 , as much as $10 \%$ and Griseofulvin $0.5 \%$.

Cosolvent can increase the solubility in water and oil and can reduce the interface tension by stabilizing the layer formed between two phases. The addition of cosurfactants can reduce the oilwater interface voltage [14].

The surfactant used in this microemulsion system is a combination of nonionic surfactants, Tween 80 , and Span 80 [13]. The use of these surfactants is relatively safe for oral administration because of their low toxicity. However, nonionic surfactants, especially those with polyoxyethylene groups, are sensitive to temperature so that they will affect the stability of the system thermodynamically. As the temperature increases, nonionic surfactants will be more lipophilic, this is due to the polyoxyethylene group that functions as a polar group or the head will become dehydrated with increasing temperature. The addition of Span 80 as a second emulsifier aims to assist Tween 80 in isolating the oil phase from microemulsion. Tween 80 with the ability as a surfactant and its chemical structure can jointly reduce the surface tension of the microemulsion system formed and increase the hydrophilic-lipophilic balance (HLB) value of Span 80 [15].

\subsection{Dosage evaluation}

3.2.1 Results of griseofulvin microemulsion stability evaluation.

The results of physical stability evaluation include organoleptic observations, $\mathrm{pH}$ observations, viscosity tests, centrifugation tests, freeze-thaw methods, and diffusion test microemulsion preparations.

\subsubsection{Organoleptic observation results}

The results of organoleptic observations of griseofulvin microemulsions with various surfactant concentrations include observations of changes in consistency, color, and odor can be seen in Table 2 .

Based on Table 2, it can be seen that the griseofulvin microemulsion preparation is stable and has no physical appearance changes during the 35day storage period at room temperature [10]. The dosage remains homogeneous, clear yellow, and has a distinctive odor derived from virgin coconut oil.

\subsubsection{Results of $\mathrm{pH}$ observation}

The results of observing the $\mathrm{pH}$ of griseofulvin. Microemulsions with various concentrations of surfactants can be illustrated in Figure 1.

The results of checking the $\mathrm{pH}$ of the four microemulsion formulas measured for 35 days showed that the $\mathrm{pH}$ of the four microemulsion formulas did not change drastically, despite a decrease and an increase in $\mathrm{pH}$ during storage [16] This shows that the preparation is chemically stable, no chemical reactions or interactions occur either with the storage container or between the ingredients contained in the preparation. $\mathrm{pH}$ measurements still indicate the $\mathrm{pH}$ that can be used by the skin (4.2-7.0) Based on statistical analysis 
Table 2: Results of organoleptic observation of griseofulvin microemulsion during 35 Days of storage

\begin{tabular}{|c|c|c|c|c|c|c|c|c|c|}
\hline \multirow[b]{2}{*}{ Formula } & \multirow[b]{2}{*}{ Parameters } & \multicolumn{8}{|c|}{ Days of Observation } \\
\hline & & 1 & 3 & 5 & 7 & 14 & 21 & 28 & 35 \\
\hline \multirow[t]{3}{*}{$\mathrm{F} 0$} & Homogenity & $\mathrm{H}$ & $\mathrm{H}$ & $\mathrm{H}$ & $\mathrm{H}$ & $\mathrm{H}$ & $\mathrm{H}$ & $\mathrm{H}$ & $\mathrm{H}$ \\
\hline & Color & $\mathrm{Y}$ & $\mathrm{Y}$ & $\mathrm{Y}$ & $\mathrm{Y}$ & Y & $\mathrm{Y}$ & $\mathrm{Y}$ & $\mathrm{Y}$ \\
\hline & Smell & $\mathrm{s}$ & $\mathrm{S}$ & $\mathrm{S}$ & $\mathrm{S}$ & $\mathrm{S}$ & $\mathrm{s}$ & $\mathrm{S}$ & $\mathrm{s}$ \\
\hline \multirow[t]{3}{*}{$\mathrm{F} 1$} & Homogenity & $\mathrm{H}$ & $\mathrm{H}$ & $\mathrm{H}$ & $\mathrm{H}$ & $\mathrm{H}$ & $\mathrm{H}$ & $\mathrm{H}$ & $\mathrm{H}$ \\
\hline & Color & $\mathrm{Y}$ & $\mathrm{Y}$ & $\mathrm{Y}$ & $\mathrm{Y}$ & $\mathrm{Y}$ & $\mathrm{Y}$ & $\mathrm{Y}$ & $\mathrm{Y}$ \\
\hline & Smell & $\mathrm{S}$ & $\mathrm{S}$ & $\mathrm{S}$ & $\mathrm{S}$ & $\mathrm{S}$ & $\mathrm{S}$ & $\mathrm{S}$ & $\mathrm{S}$ \\
\hline \multirow[t]{3}{*}{ F2 } & Homogenity & $\mathrm{H}$ & $\mathrm{H}$ & $\mathrm{H}$ & $\mathrm{H}$ & $\mathrm{H}$ & $\mathrm{H}$ & $\mathrm{H}$ & $\mathrm{H}$ \\
\hline & Color & $\mathrm{Y}$ & $\mathrm{Y}$ & $\mathrm{Y}$ & $\mathrm{Y}$ & $\mathrm{Y}$ & $\mathrm{Y}$ & $\mathrm{Y}$ & $\mathrm{Y}$ \\
\hline & Smell & $\mathrm{S}$ & $\mathrm{S}$ & $\mathrm{S}$ & $\mathrm{S}$ & $\mathrm{S}$ & $\mathrm{S}$ & $\mathrm{S}$ & $\mathrm{S}$ \\
\hline \multirow[t]{3}{*}{ F3 } & Homogenity & $\mathrm{H}$ & $\mathrm{H}$ & $\mathrm{H}$ & $\mathrm{H}$ & $\mathrm{H}$ & $\mathrm{H}$ & $\mathrm{H}$ & $\mathrm{H}$ \\
\hline & Color & $\mathrm{Y}$ & $\mathrm{Y}$ & $\mathrm{Y}$ & $\mathrm{Y}$ & $\mathrm{Y}$ & $\mathrm{Y}$ & $\mathrm{Y}$ & $\mathrm{Y}$ \\
\hline & Smell & $\mathrm{S}$ & $\mathrm{S}$ & $\mathrm{S}$ & $\mathrm{S}$ & $\mathrm{S}$ & $\mathrm{S}$ & $\mathrm{S}$ & $\mathrm{S}$ \\
\hline
\end{tabular}

Notice: $\mathrm{H}=$ Homogen ; $\mathrm{Y}=$ Clear Yellow; $\mathrm{S}=$ Specifik (oily smell)

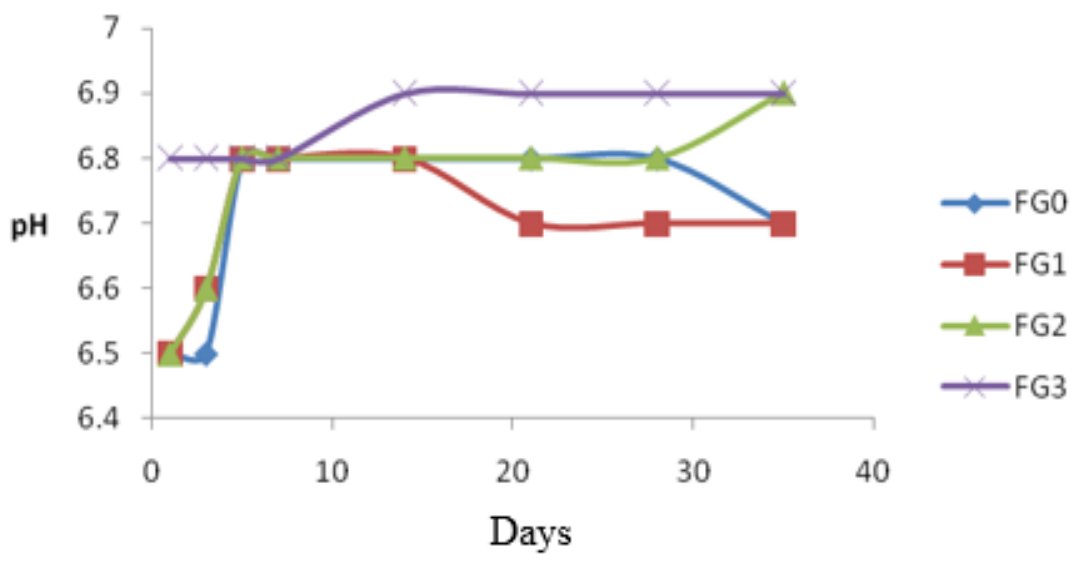

Figure 1. Graph of griseofulvin microemulsion $\mathrm{pH}$ values with variations in surfactant concentration. showed that the microemulsion preparations of

using a randomized complete block design with a confidence level of $99 \%$ or $\alpha=0.01$, it is found that the f Table value calculated results are greater than $\alpha$, meaning that $\mathrm{H} 0$ is accepted. This means the length of time of storage has no effect on the $\mathrm{pH}$ of the preparation.

\subsubsection{Viscosity observation results.}

The results of observations of the viscosity of griseofulvin microemulsions in various surfactant and cosurfactant concentrations can be seen in Figure 2.

The results of measurements of the viscosity of microemulsion preparations for 35 days using Viscometer Brookfield at room temperature $\left(27^{\circ} \mathrm{C}\right)$ formula FG0, FG1, FG2, and FG3 had viscosity which tended to increase in the first week and decreased viscosity from day 14 to day to 35 . Viscosity produced is not too large, indicating that the microemulsion preparation contains particles that can disperse well so that they have a good flow rate (300-1000 Cps). Besides, statistical analysis was also carried out on the length of time of storage and its relationship with the viscosity of microemulsion preparations [17]. Based on statistical analysis using a randomized complete block design with a confidence level of $99 \%$ or $\alpha=$ 0.01 , it was found that the $f$ Table value calculated was smaller than $\alpha$, meaning $\mathrm{H}_{0}$ was rejected. It means that the storage time affects the viscosity of 


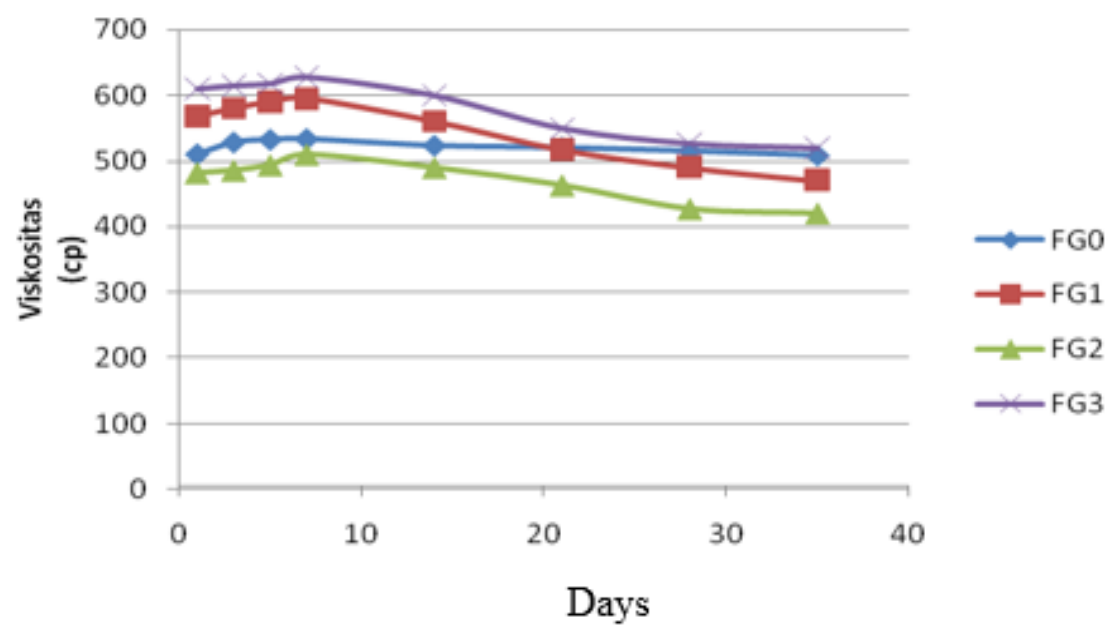

Figure 2: Graph of griseofulvin microemulsion dosage values with various surfactant concentrations.

the preparation because each formula gives a different viscosity value.

\subsubsection{Evaluation centrifugation result}

This process is an accelerated test to see the stability of preparation within a certain period. The results obtained from the four formulas tested did not occur. This shows that the preparation is still a single and clear solution. The centrifugation process is carried out for 5 hours at a speed of $3700 \mathrm{rpm}$ to find out the preparation is stable within a period of one year[18].

\subsubsection{Uji freeze-thraw}

a. Cycle at temperature $4^{\circ} \mathrm{C}$

At the time of physical stability test using the freeze-thaw method, when the preparation is stored at a low temperature $\left(4^{\circ} \mathrm{C}\right)$ it appears that the preparation has undergone a physical change ie the preparation becomes milky white and becomes viscous, and even looks solid. This is because the oil phase tends to freeze at low temperatures. As a result, the particles tend to combine to form a bond between particles that is denser which causes the preparation to become milky white because the structure becomes denser and more orderly.

\section{b. Cycle at temperature $60^{\circ} \mathrm{C}$}

The four microemulsion preparations stored at $60^{\circ} \mathrm{C}$ did not show any changes such as precipitation, rupture, or lumps which showed stable preparations at high temperatures. This shows that the water and oil phases with the help of surfactants can form a single solution that is well dispersed.

\section{c. Cycle at room temperature $\left(27^{\circ} \mathrm{C}\right)$}

Storage at room temperature $\left(27^{0} \mathrm{C}\right)$ shows that the four microemulsion preparation formulas remain stable and show no significant physical changes. The four microemulsion formulas remained clear, homogeneous, the smell and color did not change. The observation of the four microemulsion formulas stored at $4^{\circ} \mathrm{C}$ and $60^{\circ} \mathrm{C}$ for 6 cycles showed that the four formulas remained stable, did not occur in phase separation, did not break, did not form lumps, and did not undergo precipitation [11].

\subsubsection{Results griseofulvin microemulsion permeation (in vitro)}

a. Results of griseofulvin maximum wavelength determination in phosphate buffer solution pH 7.4.

Determination of the maximum wavelength of griseofulvin in phosphate buffer $\mathrm{pH} 7.4$ obtained the maximum wavelength at $296 \mathrm{~nm}$ (figure 3)[20].

Based on the measurement results of absorption of griseofulvin solution, various concentrations in phosphate buffer $\mathrm{pH} 7.4$ can be made graph of the relationship of absorption to the concentration in the form of a straight line. This shows that with the increase in concentration the amount of absorption will also increase with the linear regression equation $y=0.175+0.397$ with $r^{2}=0.995$. its proved that 


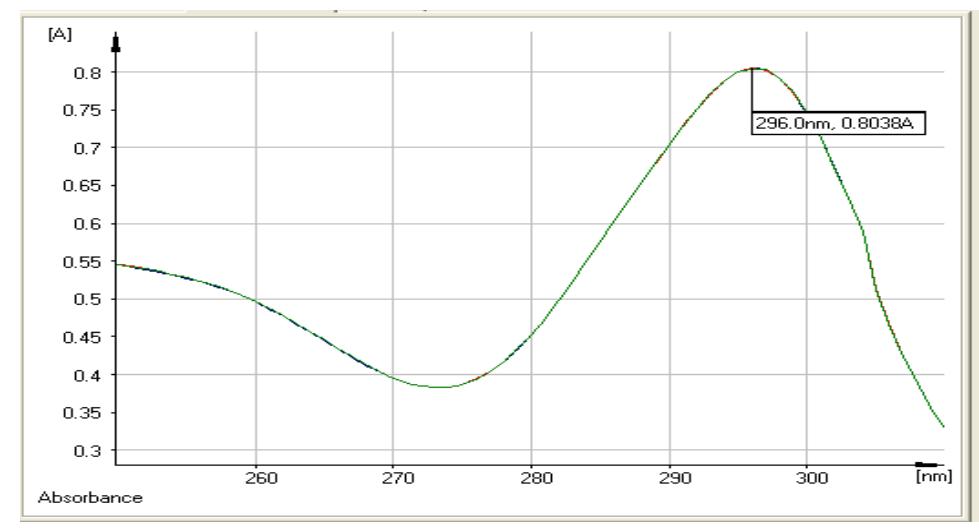

Figure 3: Maximum absorption of griseofulvin in phosphate buffer $\mathrm{pH} 7.4$

Table 3. Results of griseofulvin absorption results in phosphate buffer solution at a wavelength of $296 \mathrm{~nm}$

\begin{tabular}{lcccc}
\hline Concentration $(\mathrm{ppm})$ & $\mathrm{A} 1$ & $\mathrm{~A} 2$ & \multicolumn{1}{c}{$\mathrm{A} 3$} & \multicolumn{1}{c}{ Mean } \\
\hline 0.5 & 0.4738 & 0.4742 & 0.4753 & 0.4738 \\
1 & 0.5753 & 0.5759 & 0.5755 & 0.5755 \\
1.5 & 0.6796 & 0.6791 & 0.6796 & 0.6794 \\
2 & 0.7453 & 0.7456 & 0.7532 & 0.7480 \\
2.5 & 0.8254 & 0.8256 & 0.825 & 0.8253 \\
\hline
\end{tabular}

Notice: A: Absorbance

method for griseovulvin assay from emulsionwas validated [21].

In vitro permeation microemulsion test in vitro was carried out using Franz diffusion cells Base on data of the study it was found that the formula FG2 had the highest permeation percentages at $3.6136 \%$, while the formula FG1 had a small percent permeation at $2.0477 \%$ [22]. Whereas FG3 has a permeation percentage of $2.8724 \%$ (Table 4 and figure 4). Based on statistical analysis using a randomized complete block design with a confidence level of $99 \%$ or $\alpha=0.01$ it is found that $f$ Table is greater than $\mathrm{f}$ arithmetic then $\mathrm{Ho}$ is accepted. It means that each formula provides the same permeation rate to the cellulose membrane [23].

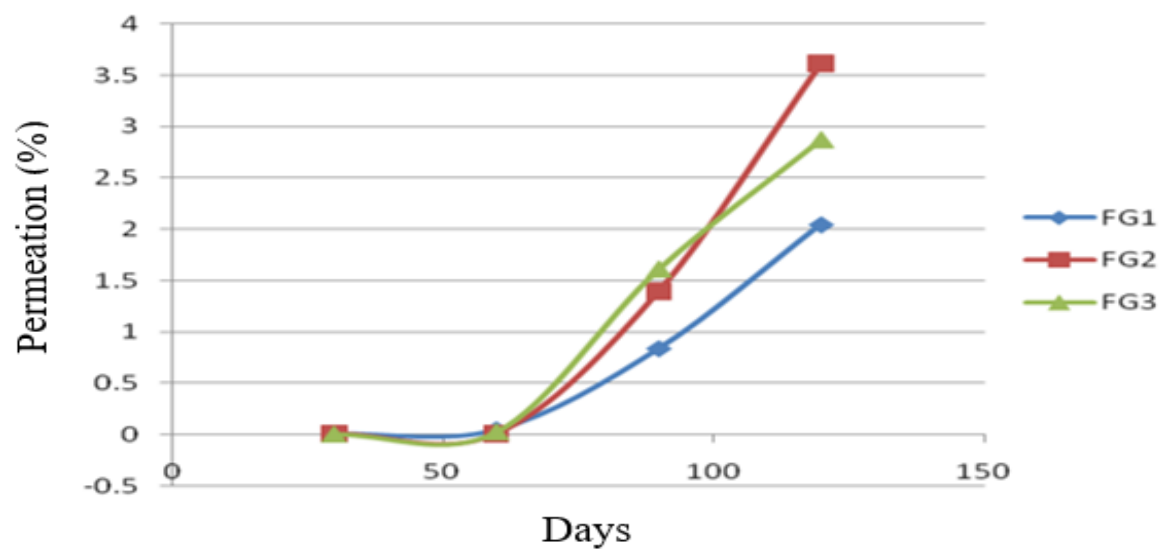

Figure 4: Profile for Microemulsion Release for 2 hours 
Table 4: Griseofulvin microemulsion permeation percentage for 2 hours.

\begin{tabular}{lccc} 
Time (minutes) & $\begin{array}{l}\text { FG1 \% } \\
\text { concentration }\end{array}$ & $\begin{array}{c}\text { FG2 } \% \\
\text { concentration }\end{array}$ & $\begin{array}{c}\text { FG3 } \% \\
\text { concentration }\end{array}$ \\
\hline 30 & 0.0079 & 0.0096 & 0.0003 \\
60 & 0.0497 & 0.0059 & 0.023 \\
90 & 0.8494 & 1.3970 & 1.6112 \\
120 & 2.0477 & 3.6136 & 2.8724 \\
\hline
\end{tabular}

\section{Conclusion}

Base on the results of the study, several conclusions were obtained: microemulsion preparations could be made using griseofulvin as a hydrophobic drug model using virgin coconut oil oil phase and tween 80 and span 80 surfactant mixtures with various concentrations, evaluation of physical stability of the four preparations was quite stable during 35 days storage, and base on permeation studi FG2 preparations have the highest percent levels compared to FG1 and FG3 for two hours.

\section{References}

1. Park K-M, Kim C-K. Preparation and evaluation of flurbiprofen-loaded microemulsion for parenteral delivery. International journal of pharmaceutics. 1999;181(2):173-179.

2. Lawrence MJ, Rees GD. Microemulsion-based media as novel drug delivery systems. Advanced Drug Delivery Reviews. 2012;64:175-93.

3. Departemen Kesehatan RI. Farmakope Indonesia Edisi IV. IV. Jakarta: Depertement kesehatan RI; 1995. 63,210,649.

4. Tjay TH, Rahardja K. Obat-obat Penting Edisi Kelima. PT Elex Media Komputindo Kelompok Gramedia: Jakarta. 2002;

5. Kamble AM. Improvment of Physicochemical Properties of griseofuvin by Recrystalization with Combination of Organics Solvents. Pharma Utility [Internet]. 2012 Oct 15

6. Lachman L, Lieberman H, Kanig JL. Teori dan praktek Farmasi Industri II (Edisi 3). Terjemahan Siti Suyatmi, Jakarta: UI Press; 2008.
7. Martins FT, Bonfilio R, De Araújo MB, Ellena J. Lamivudine salts with improved solubilities. J Pharm Sci. 2012;101(6):2143-54.

8. Gao Z-G, Choi H-G, Shin H-J, Park K-M, Lim S-J, Hwang K-J, et al. Physicochemical characterization and evaluation of a microemulsion system for oral delivery of cyclosporin A. International journal of pharmaceutics. 1998;161(1):75-86.

9. Kumar P, Mittal KL. Handbook of microemulsion science and technology. CRC press; 1999.

10. Iradhati AH, Jufri M. Formulation and physical stability test of griseofulvin microemulsion gel. Int J Appl Pharm. 2017;9:23-6.

11. Lu GW, Gao P. CHAPTER 3 - Emulsions and Microemulsions for Topical and Transdermal Drug Delivery. In: Kulkarni VS, editor. Handbook of Non-Invasive Drug Delivery Systems [Internet]. Boston: William Andrew Publishing; 2010 [cited 2020 May 31]. p. 59-94

12. Brain KR, Walters KA, Watkinson AC. Methods for studying percutaneous absorption. In: Dermatological and transdermal formulations. CRC Press; 2002. p. 215-288.

13. Guo Y, Zhao J, Yang S, Yu K, Wang Z, Zhang H. Preparation and characterization of monoclinic sulfur nanoparticles by water-in-oil microemulsions technique. Powder Technology. 2006 Mar 1;162(2):83-6.

14. Singh PJ, Khurma J, Singh A. Preparation, characterisation, engine performance and emission characteristics of coconut oil based hybrid fuels. Renewable Energy. 2010;35(9):2065-70.

15. Dehghani F, Farhadian N, Golmohammadzadeh S, Biriaee A, Ebrahimi M, Karimi M. Preparation, characterization and in-vivo 
evaluation of microemulsions containing tamoxifen citrate anti-cancer drug. European Journal of Pharmaceutical Sciences. 2017 Jan 1;96:479-89.

16. Kumar R, Sinha VR. Preparation and optimization of voriconazole microemulsion for ocular delivery. Colloids and Surfaces B: Biointerfaces. 2014;117:82-88.

17. Berthiaume MD, Merrifield JH. Microemulsions for high viscosity amino silicone fluids and gums and their preparation. Google Patents; 1996.

18. Wiechers JW. Optimizing skin delivery of active ingredients from emulsions: from theory to practice. In: Delivery system handbook for personal care and cosmetic products. Elsevier; 2005. p. 409-436.
19. Cm J, Vk K, Payghan SA. Stability Study of Griseofulvin in Non Aqueous Microemulsion System. 2014;

20. Rowe RC, Sheskey P, Quinn M. Handbook of pharmaceutical excipients. Libros DigitalesPharmaceutical Press; 2009.

21. Snyder LR, Kirkland JJ, Glajch JL. Practical HPLC Method Development. John Wiley \& Sons; 2012. $813 \mathrm{p}$.

22. Kantarc1 G, Özgüney I, Karasulu HY, Güneri T, Başdemir G. In vitro permeation of diclofenac sodium from novel microemulsion formulations through rabbit skin. Drug development research. 2005;65(1):17-25.

23. Nandi I, Bari M, Joshi H. Study of isopropyl myristate microemulsion systems containing cyclodextrins to improve the solubility of 2 model hydrophobic drugs. AAPS PharmSciTech. 2003;4(1):71-79. 